\title{
Re-exploration of Pancasila as an Improvement in The Quality of Moral Education for The Indonesian Nation
}

\author{
Ulfiani Mabruroh \\ Universitas Sebelas Maret, Surakarta, Indonesia \\ ulfianimabruroh@gmail.com
}

\section{Article History}

accepted 23/03/2021

approved 10/04/2021

published 20/04/2021

\begin{abstract}
This think about point to depict the planting of the center values of Pancasila-based character instruction to shape understudies as youthful individuals who are great, shrewdly, and adore the homeland. This inquire about is included in library inquire about, so the information source utilized is library information, both within the shape of diaries, book and magazines. In this case there are two types of information source utilized, to be specific essential information sources and auxiliary information sources. Essential information sources are information sources that are straightforwardly related to the subject. Whereas secondary information sources are information sources supporting subjects determined from different considers. The comes about of the examination appear that the teaching of the center values of Pancasila-based character instruction to understudies in schools is exceptionally critical to carry out, since it contains the values of devout character, social care, autonomy, national soul, popular governmet, resilience, and teach. The teaching of the center values of Pancasila based character instruction for understudies in schools is done through the educating and learning process.
\end{abstract}

Keywords: value cultivation, character education, Pancasila

\section{Abstrak}

Penelitiannya bertujuan mendeskripsikan penanaman nilai-nilai inti berbasis Pancasila pendidikan karakter untuk membentuk peserta didik sebagai anak muda yang baik, cerdas, dan penyayang tanah air. Penelitian ini termasuk dalam penelitian pustaka, sehingga sumber data yang digunakan adalah data perpustakaan, baik berupa jurnal, buku maupun majalah. Dalam hal ini ada dua jenis sumber data yang digunakan yaitu sumber data primer dan sumber data sekunder. Sumber data primer adalah sumber data yang berhubungan langsung dengan tema. Sementara Sumber data sekunder adalah sumber data yang menunjang tema yang berasal dari berbagai penelitian. Hasil analisis menunjukkan bahwa penanaman nilai-nilai inti berbasis Pancasila Pendidikan karakter kepada siswa di sekolah sangat penting dilakukan, karena itu mengandung nilai-nilai budi pekerti, kepedulian sosial, kemandirian, jiwa bangsa, demokrasi, toleransi, dan disiplin. Penanaman nilai-nilai inti pendidikan karakter berbasis pancasila kepada siswa di sekola dilakukan melalui pembelajaran dan proses pembelajaran.

Kata Kunci: penanaman nilai, pendidikan karakter, Pancasila

Social, Humanities, and Education Studies (SHEs): Conference Series https://jurnal.uns.ac.id/shes

p-ISSN 2620-9284

e-ISSN 2620-9292 


\section{PENDAHULUAN}

Globalisasi adalah era keterbukaan terhadap dunia luar. masalah ini Masyarakat dituntut untuk memiliki keterampilan komunikasi yang memadai Bisa bertahan dari tren globalisasi. Proses globalisasi Akan terus berdampak pada perubahan karakteristik masyarakat Indonesia. Kemajuan teknologi yang tak terbatas ini perlahan akan mengikis karakter negara.

Efek positif dari globalisasi adalah kemudahan akses informasi Mendorong tumbuh dan berkembangnya ilmu pengetahuan dan teknologi. Namun, globalisasi juga dapat berdampak negatif pada kehidupan di negara tersebut. negara. Globalisasi sangat mempengaruhi penerapan unsur identitas nasional. Konflik antara nilai-nilai internal dan eksternal bangsa Indonesia akan membawa konflik ideologi nasional Indonesia. Gagasan bangsa Indonesia adalah Pancasila, dan Pancasila adalah landasan Pancasila Itu adalah negara dan negara bagian Indonesia.

Pendidikan merupakan salah satu hal yang sangat penting dalam persiapan Generasi muda yang akan datang. Pendidikan berkualitas akan memungkinkan Generasi penerus bangsa dapat memberikan kontribusi positif untuk perbaikan Merespon dinamika perubahan masalah di masyarakat. Dalam hal ini pendidikan Ini juga akan menjadi pelengkap bagi sekolah, masyarakat, negara dan kehidupan negara Sebagai wujud ekspresi nilai budaya dan ciri khas suatu negara. namun, Momentum perkembangan saat ini di masyarakat dan sekolah sedang berlangsung Dalam globalisasi yang semakin dahsyat, nilai karakter siswa semakin merosot. Pengaruh kuat dari kehidupan global telah meningkatkan tatanan dan sikap siswa Cenderung bertentangan dengan nilai-nilai positif yang sudah dipraktekkan sejak lama Pendiri negara (Santoso, 2017).

Upaya yang dapat dilakukan dalam menghadapi dampak negatif globalisasi Dengan menanamkan nilai karakter pada siswa. Kata Aan Hasanah Ketika berbicara tentang nilai-nilai dalam pendidikan karakter, itu pasti mungkin Mengajar (bisa diajar) di rumah, sekolah dan komunitas. Dimana nilainya Disepakati bersama dan secara umum dianggap sebagai nilai terbaik untuk uang. Nilai Ini bersifat indikatif karena dapat mengarah pada perilaku yang baik, Bertanggung jawab dan mencapai tujuan pendidikan nasional (Widiantari, 2017).

Sebagai falsafah dan ideologi bangsa Indonesia. Pancasila merupakan landasan bagi bangsa Indonesia untuk mewujudkan segala aspek kehidupan. Salah satunya di bidang pendidikan. Pancasila memiliki lima nilai ciri utama yang menjadi fokus pengembangan gerakan PPK yaitu agama, nasionalisme, integritas, kemandirian, dan gotong royong. Setiap nilai tidak diisolasi, tetapi saling mempengaruhi, dapat berkembang secara dinamis dan membentuk satu kesatuan yang personal (Kemendikbud, 2017).

Pertama, nilai karakter religius yang mencerminkan keimanan Berperilaku sebagai dewa yang maha kuasa yang menjalankan doktrin agama Pertahankan keimanan, hargai perbedaan agama, dan pertahankan sikap Toleransi terwujudnya ibadah agama dan kepercayaan lainnya, hidup rukun, Hidup damai dengan pemeluk agama lain. Menunjukkan realisasi nilai tokoh agama ini Dengan sikap cinta damai, toleransi, dan menghormati perbedaan agama dan keyakinan, Ketekunan, percaya diri, kerjasama antara agama dan keyakinan, anti Bullying dan kekerasan, persahabatan, ketulusan, tanpa memaksakan keinginan seseorang, Cintai lingkungan dan lindungi orang-orang kecil dan tersisih.

Kedua, nilai karakter nasionalis adalah cara berpikir, bertindak dan bertindak Tunjukkan kesetiaan, perhatian, dan rasa hormat yang tinggi Bahasa, lingkungan alam, sosial, budaya, ekonomi dan politik negara, Kepentingan negara dan negara lebih tinggi dari pada kepentingan diri sendiri dan kelompoknya. sikap Mengekspresikan nasionalisme dengan menghargai budaya negaranya sendiri dan menjaga sikap berbangsa. Kekayaan budaya negara, rela berkorban, melampaui dan menyadari, 
mencintai tanah air, Lindungi lingkungan, patuhi hukum, disiplin, hormati budaya, ras, dan keragaman agama.

Ketiga, nilai ciri integritas adalah nilai yang menjadi dasar berperilaku Berdasarkan menjadikan diri Anda orang yang dapat dipercaya selamanya Dalam kata-kata, tindakan dan pekerjaan, dia memiliki komitmen dan kesetiaan pada nilai-nilai dan etika kemanusiaan. Ciri integritas meliputi rasa tanggung jawab sebagai warga negara, partisipasi aktif dalam kehidupan bermasyarakat melalui tindakan berbasis kebenaran dan konsistensi tutur. Orang yang jujur juga menghargai Martabat pribadi (terutama penyandang cacat) dan mampu menunjukkan model.

Keempat, nilai karakter mandiri adalah sikap dan perilaku mandiri Berikan kepada orang lain dan gunakan semua energi, pikiran dan waktu untuk berprestasi Harapan, impian dan cita-cita. Mahasiswa mandiri harus memiliki etika profesi yang baik, Keuletan, semangat juang, profesionalisme, inovasi, keberanian dan pembelajar Seluruh hidup.

Kelima, nilai kualitas gotong royong mencerminkan perilaku menghargai semangat gotong royong, bergotong royong memecahkan masalah bersama, menjalin komunikasi dan persahabatan, serta memberikan bantuan kepada yang membutuhkan. perlu. Harapkan siswa untuk menunjukkan rasa hormat kepada orang lain Saling bekerjasama, bertoleransi, dan mampu mengambil keputusan bersama serta melakukan musyawarah Capai konsensus, tolong bantu, miliki empati, solidaritas, anti diskriminasi, anti diskriminasi Sikap kekerasan dan kesukarelaan.

Upaya pembinaan karakter bangsa sejak dini melalui pendidikan Apakah langkah yang tepat. Kembangkan karakter siswa Strategi berdasarkan filosofi nasional menjadi semakin penting dan strategis, terutama jika Terkait tantangan yang dihadapi Indonesia dalam mempersiapkan generasi penerus Masa depan akan menghadapi masalah yang kompleks dan menantang Berusaha keras untuk mewujudkan cita-cita luhur bangsa Indonesia berdasarkan falsafah kebangsaan Indonesia yaitu Pancasila.

\section{METODE}

Penelitian ini termasuk dalam library research, sehingga digunakan sumber datanya dengan menyusun data perpustakaan dalam bentuk terbitan berkala, buku atau majalah. Dalam keadaan ini dua jenis sumber data yang digunakan yaitu sumber data utama dan sumber data Minor. Sumber data utama adalah sumber data yang berhubungan langsung dengan subjek. Sumber data sekunder merupakan sumber data yang mendukung topik-topik berbagai penelitian.

\section{Penanaman nilai}

\section{HASIL DAN PEMBAHASAN}

Menanam adalah suatu tindakan atau cara menanamkan (Purwadarminta, 1984). Artinya bagaimana guru bekerja keras untuk menanamkan nilai-nilai pendidikan Karakter siswa didasarkan pada pemahaman berbagai pengetahuan Kondisi belajar yang berbeda. Nilai ini berasal dari bahasa Latin "vale're", yang artinya Menunjukkan berguna, mampu diotorisasi dan valid untuk menafsirkan nilai sebagai Menurut keyakinannya sendiri dianggap baik, bermanfaat dan paling benar Atau sekelompok orang (Sutarjo Adisusilo, 2012a).

Ada dua jenis nilai yaitu nilai dasar dan nilai alat. Nilai dasar Ini adalah nilai yang tidak dapat diubah dan tidak dapat diubah lagi. Meski layak Perantaraan adalah nilai yang langsung dijelaskan dalam kehidupan Sebagai arah kehidupan nyata setiap hari, nilai alat harus ada di dalamnya Ini masih mengacu pada nilai dasar, jadi tidak akan ada konflik antara nilai alat Dan nilai dasar (Widiantari, 2017).

Menurut Raths (Sutarjo Adisusilo, 2012b), nilai adalah Ringkasan tersebut memiliki banyak indikator yang dapat diamati, termasuk: 
1. Nilai memberikan tujuan atau arah (goal atau tujuan) yang harus dicapai kehidupan Menuju, harus dikembangkan dan dibimbing

2. Nilai dapat membawa ambisi atau inspirasi bagi seseorang Menjadi baik untuk kehidupan, berguna dan positif

3. Nilai dapat memandu perilaku seseorang (sikap), atau Bertindak sesuai dengan etika sosial.

4. Nilai-nilai ini menarik (minat) dan menarik pemikiran batin orang, Pertimbangkan, miliki, perjuangkan, dan hidup

5. Nilai dapat mengganggu perasaan (feeling) orang lain, hati nurani seseorang Rasakan semua jenis kebahagiaan, kesedihan, depresi, Sangat gembira

6. Nilai berhubungan dengan keyakinan atau keyakinan Seseorang yang keyakinan atau keyakinannya terkait dengan nilai-nilai tertentu

7. Nilai biasanya muncul dalam kesadaran, hati nurani atau pikiran seseorang Ketika orang yang bersangkutan bingung, terjebak dalam dilema, atau Menghadapi berbagai masalah kehidupan (kekhawatiran, masalah, hambatan)

\section{Pendidikan Karakter}

Pendidikan karakter merupakan sistem yang menanamkan nilai-nilai karakter kepada warga negara Sekolah termasuk komponen pengetahuan, kesadaran, kemauan dan tindakan Menuju Tuhan Yang Maha Esa dan menerapkan nilai-nilai tersebut sendiri Tetangga, lingkungan, dan kebangsaan membuat mereka menjadi orang yang sempurna (Novan Ardy Wiyani, 2012). Istilah pendidikan karakter semakin dikenal di kalangan masyarakat Indonesia saat ini. khususnya Dilihat dari tingkah laku peserta, ia merasakan berbagai ketimpangan dalam prestasi pendidikannya Mahasiswa, seperti perkelahian, pembunuhan, perampokan, narkoba dan pengangguran lulusan SMP dan SMA. Saat negara ini dilanda krisis, segalanya akan menjadi lebih kuat Mereka tidak pernah mengalami krisis (Dharma Kesuma, 2011).

Karakter adalah gambaran tingkah laku, menekankan nilai benar atau salah, Baik dan buruk, baik eksplisit maupun implisit. Karakter disebutkan dengan lebih jelas Rangkaian sikap (attitude), tingkah laku (behaviour), motivasi (motif) dan Keterampilan. Kepribadian mencakup sikap, seperti keinginan untuk melakukan sesuatu Kemampuan intelektual yang terbaik, seperti berpikir kritis dan penalaran moral, perilaku Seperti bersikap jujur dan bertanggung jawab, menjunjung tinggi prinsip etika yang dalam Situasi yang penuh dengan ketidakadilan, hubungan interpersonal, dan keterampilan emosional Izinkan seseorang untuk berinteraksi secara efektif dalam berbagai situasi, dan Komitmen untuk berkontribusi pada komunitas dan masyarakat (Ngainun Naim, 2012). Menurut Lickona, peran terkait dengan konsep moral (kognisi moral), Sikap moral (moral touch) dan perilaku moral (moral behaviour). Berdasarkan ketiganya Dapat dikatakan bahwa komponen ini adalah karakter yang baik didukung oleh pengetahuan Mengenai kebaikan, keinginan untuk melakukan perbuatan baik.

Pendidikan karakter di lingkungan sekolah merupakan proses pembelajaran Mengarah pada penguatan dan pengembangan perilaku siswa secara keseluruhan Menurut nilai tertentu yang disebutkan oleh sekolah. Definisi tersebut mengandung artinya adalah: 1 . Pendidikan karakter merupakan gabungan antara pendidikan dan pembelajaran Terjadi di semua mata pelajaran 2. Berkomitmen untuk memperkuat dan mengembangkan perilaku siswa Utuh, di mana siswa memiliki Potensi untuk diperkuat dan dikembangkan 3. Memperkuat dan mengembangkan perilaku berdasarkan nilai-nilai yang disebutkan di bawah ini Sekolah (Dharma Kesuma, 2011).

Intinya, sekolah itu Membentuk kepribadian dan perilaku moral siswa yang gigih Nilai-nilai universal dalam kehidupan sekolah juga dapat memberikan 
pemahaman dan Kubu mahasiswa untuk menghindari keterikatan negatif di media informasi (Muslimatun, 2015). Intinya tujuan pendidikan karakter adalah membentuk bangsa, Kuat, kompetitif, mulia, etis, toleran, kooperatif, membangkitkan semangat Patriotik, perkembangan dinamis, berorientasi pada teknologi Semuanya penuh kehidupan dengan iman dan pengabdian mereka kepada Tuhan Yang Maha Esa Berdasarkan Pancasila (H. Gunawan, 2012).

\section{Pancasila}

Secara etimologis, Pancasila berasal dari kata Panca yang artinya lima, sedangkan Syiila Arti dasar. Jika digabungkan, Pancasila mengandung lima makna dasar. di Soekarno berpidato pada 1 Juni 1945, tanpa menyebut Pancasila menjadi teks Yayasan Nasional. Pada 17 Agustus 1945, Indonesia mengumumkan pendiriannya Kemerdekaan, keesokan harinya, UUD 1945 disahkan pada 18 Agustus 1945 Termasuk pembukaan berdasarkan 5 prinsip Negara (ideologi) disebut Pancasila. Sejak itulah istilah Pancasila menjadi Bahasa Indonesia yang biasa digunakan oleh orang Indonesia. Lanjut Pancasra dielu-elukan sebagai ideologi bangsa Indonesia (Dianasari, 2018).

Secara umum, ideologi adalah pemikiran, kumpulan pemikiran, Keyakinan yang komprehensif dan sistematis di berbagai bidang Kehidupan manusia. Artinya cita-cita negara atau cita-cita yang menjadi dasar dari sesuatu Semua orang yang relevan dan sistem negara negara Esensinya adalah prinsip spiritual yang sangat khas Sebagai nilai kehidupan berbangsa dan bernegara, serta mewujudkan prinsip Spiritualitas, pandangan dunia, cara hidup, cara hidup yang dipupuk, Kembangkan, praktikkan, pertahankan, dan perjuangkan untuk generasi berikutnya Jaga kesediaan untuk berkorban (Dinas Pemuda dan Jasmani, 2016).

Pancasila adalah ideologi yang menjadi tumpuan negara Yang mengandung nilai-nilai luhur sebagai solusinya Masalah internal dan eksternal bahkan sangat besar Berhubungan erat dengan kemajuan zaman dan mampu mengatasi tantangan Di depannya. Masih bagaimana mewujudkan nilai luhur yang melekat Dalam kehidupan sehari-hari Pancasila. Ideologi suatu negara adalah perspektif organisasi Negara, karena ideologi adalah sistem nilai, yang meliputi: 1) Nilai dasar Ini adalah pilihan ideal, dan 2) nilai pahat digunakan sebagai metode atau Bagaimana mewujudkan cita-cita tersebut (Dianasari, 2018).

Sebagai landasan negara, Pancasila digunakan sebagai ketertiban hukum Indonesia atau Semua sumber hukum yang mengatur kehidupan berbangsa dan sosial. Tetapkan Pancasila sebagai landasan negara, kemudian akhlak Pancasila menjadi akhlak Negara (Soejadi, 1994). Sosialisasi dan rooting Pancasila harus dilakukan dengan satu cara Percakapan dan kontekstual agar nyaman dan relevan dengan masalah saat ini Rakyat dan bangsa Indonesia. Saat generasi nasional percaya Pengetahuan saya sendiri tentang kebenaran dan merasakan manfaat pancasila dalam hidup. Untuk itu, semua pihak harus menyadari bahwa Pancasila ada hubungannya dengan kita, Untuk kami, untuk kami. Realisasinya tidak bisa menunggu peran negara, tapi Itu menjadi tanggung jawab semua pihak (Latif, 2017).

Sebagai ciri inti negara Indonesia, Pancasila terdiri dari lima pilar Karakter, yaitu:

1. Melampaui dan menyadari bahwa manusia adalah ciptaan Tuhan Seseorang darinya hanya akan membawa perbudakan kepada Tuhan, Kesadaran ini juga berarti mengetahui keberadaan dan lingkungan alam sendiri, jadi Bisa makmur

2. Humanisasi, semua orang kecuali Tuhan pada dasarnya sama Agama dan ilmu yang khas, manusia diciptakan sebagai subyek dengan potensi

3. Keanekaragaman, ketahuilah bahwa ada banyak perbedaan di dunia Kemampuan untuk mengambil pendirian bersama untuk mengembangkan kekuatan;

4. Pembebasan, pembebasan dari penindasan rekan senegaranya, oleh karena itu tidak Koloni manusia yang dibenarkan; dan, 
5. Keadilan adalah kunci kemakmuran, tetapi keadilan tidak berarti kesetaraan Proporsi (I.Gunawan, 2012).

\section{Penanaman Nilai Pendidikan Karakter Berlandaskan Pancasila}

Menanamkan nilai-nilai inti pendidikan peran berbasis Pancasila di kalangan peserta didik Tujuan siswa sekolah adalah agar mereka terbiasa dengan tingkah laku dan tingkah laku Perilaku tersebut sejalan dengan nilai-nilai Pancasila. Selain itu, penanaman nilai-nilai inti Berdasarkan pendidikan peran Pancasila, membuatnya berurat-berakar di hati masyarakat Jiwanya berakar dalam dan menjadi generasi masa depan positif. Menanamkan nilai-nilai inti pendidikan peran berbasis Pancasila ke dalam Ketika segala jenis informasi mulai berkembang, siswa menjadi kebutuhan Tersebar di dunia maya. Nilai-nilai inti ini adalah benteng mereka Tak mudah melupakan budaya negeri ini. Belajar memahami atau Ideologi datang dari luar, tapi hati-hati karena kita lahir dan besar di Indonesia. Indonesia sudah memiliki ideologi nasional yang bisa mempersatukan semua orang Unsur sosial yaitu Pancasila (Pancasila).

Lima perintah Pancasila mengajari kita untuk tetap bersyukur dan Didedikasikan untuk Tuhan Yang Maha Esa, manusiawi, menjaga persatuan Bersatu dan ajari Dapatkan solusi untuk mewujudkan keadilan sosial bagi seluruh rakyat Indonesia. Upaya menanamkan nilai inti pendidikan peran yang berlandaskan Pancasila Kepada siswa, tentu saja tidak hanya sekedar lulus sekolah Serangkaian kegiatan belajar mengajar juga dapat dicapai melalui kebiasaan yang tertanam kuat kehidupan. Kebiasaan lebih dari sekedar mengajarkan pengetahuan tentang berbagai hal Benar dan salah, Anda juga bisa merasakan nilai kebaikan dan apa Tidak baik, dan mau melakukannya, dari lingkaran terkecil dalam keluarga sampai Memiliki jangkauan yang lebih luas di masyarakat.

Peran guru dan orang tua sangat penting Memungkinkan siswa menjadi akademis dan non-akademis. Teladan guru dan orang tua merupakan faktor utama keberhasilan dalam menanamkan nilai-nilai inti Pendidikan karakter di sekolah dan rumah. Guru di Melaksanakan pendidikan karakter di sekolah. Pada saat yang sama, orang tua harus berperan Tumbuhkan kepribadian di rumah agar apa yang Anda ajarkan bisa sukses Itu semua berdasarkan keinginan siswa, guru dan orang tua. Maka ketiganya harus Berkolaborasi dalam mencapai perilaku yang baik (Wibowo, 2012). Dalam hal ini, Masdar Farid meyakini hal itu pada paragraf keempat Pembukaan UUD 1945 memuat lima prinsip dasar, Membangun dan mewujudkan kehidupan bermasyarakat, berbangsa dan bernegara. Kelima prinsip dasar tersebut disebut Pancasila (Yusuf, 2013).

Nilai-nilai inti pendidikan Karakter berbasis pancasila yang harus ditanamkan pada diri siswa Sekolah, termasuk:

1. Perintah pertama, aturan tertinggi Hardono Hadi berpendapat bahwa negara tersebut perlu ditegaskan secara jelas Indonesia telah menemukan prinsipprinsip dasar yang dapat mempersatukan segalanya. Prinsip pertama Inilah sikap terdalam bangsa Indonesia (Yusuf, 2013) yang artinya selain nilai sakral dan religius, pada perintah pertama, Ada juga nilai persatuan dan kesatuan, yang mengikat umat manusia menjadi satu Percaya pada Tuhan Yang Maha Kuasa dan Pencipta. Nilai Tuhan Yang Maha Esa dalam perintah pertama dapat dicapai Pelajari beberapa referensi untuk nilai. Selama ini nilai toleransi hanya Wacana sulit dilaksanakan karena hanya bertumpu pada tataran kognitif. Hal ini menyebabkan kelemahan karakter masyarakat. Sekolah seharusnya Kemampuan untuk mencoba memecah perintah pertama menjadi komponen yang berharga Pendidikan karakter tumbuhan (Angkasa, 2010).

2. Perintah kedua, kemanusiaan yang adil dan beradab Nilai yang terkandung dalam perintah ini adalah setiap masyarakat Indonesia Berharap untuk dapat 
memperlakukan orang lain dan menganggap semuanya baik-baik saja Memiliki derajat, hak dan kewajiban yang sama dengan warga negara Indonesia. mohon untuk Ini juga menekankan perlunya memiliki sikap ramah, cinta dan suka satu sama lain Melaksanakan kegiatan kemanusiaan (Oktavianus, 2019). Pandangan di atas dibenarkan oleh Darji Darmodiharjo yang mengatakan Adanya nilai-nilai kemanusiaan berupa pengakuan harkat kemanusiaan, Perlakukan manusia dengan adil. ini berarti Kreatifitas, rasa, niat dan keyakinan sehingga manusia dan Hewan (Gifari, 2018).

Kemanusiaan yang adil dan beradab adalah bagian penting dari rantai ini Karakter nasional. Artinya, peradaban manusia merupakan modal utama umat manusia. hubungan sosial. Salah satu faktor dalam pendidikan kemampuan adalah kemampuan Dengan seperti Kerapian, kebersihan pribadi, dan ketekunan adalah proses pembelajaran Peradaban (Angasa, 2010).

3. Perintah ketiga, penyatuan Indonesia Perintah ini mengandung nilai-nilai yang diharapkan dari bangsa Indonesia Tunjukkan sikap cinta terhadap negara atau nasionalisme dengan cara tertentu Mengutamakan persatuan dan kesatuan nasional di atas kepentingan Individu atau kelompok. Hal ini tercermin dari keharmonisan antara satu sama lain Yang lainnya, jangan mempertanyakan perbedaannya (Oktavianus, 2019).

Wafi (2019) berpendapat bahwa memahami konsep persatuan Indonesia bisa Itu dilakukan dengan mengenalkan budaya Indonesia melalui tubuh. Berbagai tempat Hikmah di seluruh wilayah Republik Indonesia bisa menjadi pintu masuk pemahaman Persatuan dan cinta tanah air. Karakteristik ini dapat diberikan oleh arsitektur Membawa kreativitas siswa bercirikan budaya melalui kegiatan ekstrakurikuler Lebih menarik bagi siswa. Guru juga dapat memanfaatkan kemajuan teknologi informasi Dan dengan komunikasi berbasis audiovisual (TIK) dapat ditampilkan Tunjukkan kepada siswa betapa kayanya Indonesia dalam hal tradisi, ras, bahasa, dan keragaman budaya Permudah pembelajaran. Angkasa (2010) membenarkan pandangan di atas bahwa proses cinta tanah air Tentu saja tidak diperlukan cara yang sangat abstrak. Dapat membuat peran ini Tentunya dengan menumbuhkan kreativitas siswa tetap memiliki ciri khas Budaya Daerah.

Kreativitas siswa sangat erat kaitannya dengan kemampuan pemahaman yang mendalam kemampuan kognitif). Dengan bantuan teknologi, kita bisa memperkenalkan keberagaman daerah. Tidak hanya itu, proses kreativitas pun semakin mudah Dengan bantuan teknologi. Kecintaan pada negara bisa sangat terbantu dengan cara-cara berikut Munculnya alat-alat modern membuat pengajaran kita lebih mudah dan lebih menarik.

4. Perintah keempat, penduduk dibimbing oleh kebijaksanaan Musyawarah / Representasi Nilai-nilai kerakyatan yang terkandung di negara Indonesia bersumber dari rakyat, rakyat, Artinya, untuk rakyat, semua kebijakan dan keputusan otoritas nasional harus Sejalan dengan keinginan dan minat masyarakat. Selain itu, kebijakan Dan harus membuat berbagai keputusan melalui musyawarah dan negosiasi kolektif Perwakilan Rakyat (Yussuf, 2013).

Konsep di atas menunjukkan bahwa siswa sedang Pentingnya musyawarah agar keputusan yang diambil merupakan keputusan bersama Ini bukan keputusan individu atau kelompok. Seperti yang dikatakan Soegito, Etika dalam kehidupan berbangsa dan bernegara Pancasila adalah salah satunya yaitu Politik dan etika pemerintahan bertujuan untuk menciptakan pemerintahan yang baik Bersih, efisien dan efektif, serta menciptakan suasana politik demokrasi yang dalam Kesopanan dalam perilaku toleransi politik, tidak berpura-pura, Jangan sombong, jauhi kemunafikan dan jangan berbohong, tidak manipulatif dan perilaku tercela lainnya. Kedua belah pihak sepakat (Saprul, tt). 
Hal inilah yang dapat tersampaikan ketika peserta didik mempelajari pendidikan karakter. Perkenalkan siswa pada prosedur yang benar dan ikuti aturan / prinsip yang berlaku. benda Ini bukan untuk membuat siswa patuh, melainkan mengajak orang lain Mereka menjadi orang yang penurut. Ketaatan adalah bagian dari disiplin, begitu juga perintah Sebelum empat langkah ini, pelatihan disiplin diri dapat diberikan untuk mengapresiasi Sebuah proses yang melibatkan orang lain.

5. Perintah kelima, keadilan sosial bagi seluruh rakyat Indonesia Ini adalah fondasi yang sangat mendasar dari kepekaan sosial. orang itu Karakter, pertanda bisa memperjuangkan orang lain, bukan untuk dia sendiri. Inilah makna keadilan sosial, keadilan sosial tidak lagi diperlukan Diskusikan dalam rentang yang luas dan melamun, tetapi diskusikan dalam aktivitas sehari-hari siswa. Apakah siswa memiliki simpati kepada siswa lain? apa ini Hal tersebut dapat dijelaskan dalam pembelajaran sehari-hari (Angkasa, 2010).

Karakteristik inilah yang menjadi fondasi kepekaan sosial dan aset dasar siswa Selalu berdiri di atas semua orang dan berjuang untuk kebaikan bersama, Tidak cocok untuk dirinya dan timnya. Dalam konteks pembelajaran, keadilan Persoalan sosial seharusnya tidak lagi dibahas dalam lingkup abstrak dan luas, tetapi harus berakar pada kenyataan Dalam aktivitas siswa sehari-hari. Misalnya, perhatikan apakah mereka mengungkapkan perasaan, simpati, dan simpati mereka kepada teman lain Apakah (Wafi, 2019). Perilaku di atas masih bersifat tentatif dan dapat dijelaskan lebih detail. Sehingga benar-benar menjadi kode etik setiap anak di tanah air. Dalam proses implementasi, standar tersebut harus berupa kode etik, bukan kode etik. Perilaku kompulsif haruslah manusiawi, sejalan dengan fitrah manusia, dan harmonis Dalam implementasinya manusia sebagai individu dan masyarakat. Nilai-nilai Pancasila Hal ini perlu direvitalisasi melalui proses komunikasi yang serius, menggunakan metode rasional yang tepat dan ilmiah daripada metode indoktrinasi. Jangan Melalui metode pendidikan persuasif, tidak pernah ada unsur paksaan.

\section{SIMPULAN}

Menumbuhkan nilai-nilai inti pendidikan karakter bertujuan untuk menghidupkan kembali Karakter kewarganegaraan berdasarkan nilai-nilai Pancasila. Terutama nilai Dedikasi, iman, kejujuran, kepedulian, nilai moral dan kesopanan. Sekolah merupakan salah satu cara yang tepat untuk menanamkan nilai-nilai inti Pendidikan karakter berdasarkan Pancasila kepada peserta didik. karena Nilai inti pendidikan karakter menanam pohon pada dasarnya adalah menciptakan peserta Mahasiswa menjadi warga negara yang demokratis dan berkarakter sejalan dengan nilai-nilai Pancasila.

\section{DAFTAR PUSTAKA}

Angkasa, kingkin T. (2010) Pendidikan Karakter Berbasis Pancasila, Kompas, https://amp.kompas.com/edukasi/read/2010/12/06/11371340/pendidikan.karakt e r.berbasis.pancasila

Dharma Kesuma, D. (2011) Pendidikan Karakte:Kajian Teori dan Praktik di Sekolah. Bandung: PT Remaja Rosdakarya.

Dianasari, D. (2018) 'Penanaman Karakter Siswa Melalui Transfer Nilai-nilai Pancasila Pada Mata Pelajaran Budi Pekerti', Prosiding Seminar Nasional Pendidikan FKIP Universitas Muhammadiyah Cirebon 2018, (April), pp. 181-192.
Disdik
Pemuda
dan Olahraga
(2016)
Pengertian
Ideologi, https://bulelengkab.go.id/detail/artikel/artikel-pengertian-ideologi-35. 
Gifari, A. (2018) 'Implementasi Nilai-Nilai Pancasila Dalam Menumbuhkan Nasionalisme di Lingkungan Sekolah Islam', Juridiksiam Jurnal Pendidikan Sosial dan Keberagaman Universitas Mataram, (1).

Gunawan, H. (2012) Pendidikan Karakter Konsep dan Implementasi. Bandung: Alfabeta.

Gunawan, I. (2012) 'Pendidikan karakter di Tingkat Sekolah Dasar Meretas Sekolah Humanis Untuk Mendesain Siswa Sekolah Dasar (SD) yang Cerdas dan Berkarakter', Prosiding Seminar Nasional dan Call For Papers.

Kemendikbud (2017) Penguatan Pendidikan Karakter Jadi Pintu Masuk Pembenahan PendidikanNasional,https://www.kemdikbud.go.id/main/blog/2017/07/penguatan -pendidikankarakter-jadi-pintu-masuk-pembenahan-pendidikan-nasional.

Latif, Y. (2017) Pancasila Untuk Dunia. Jakarta: PT. Enka Parahiyangan.

Muslimatun (2015) Implemantasi pendidikan karakter dalam pembelajaran sejarah kelas xi iis di sma islam sudirman ambarawa tahun ajaran 2014/2015.

Ngainun Naim (2012) Character Building: Optimalisasi Peran Pendidikan dalam Pengembangan IImu \& Pembentukan Karakter Bangsa. Jogjakarta: AR-RUZZ MEDIA.

Novan Ardy Wiyani (2012) Pendidikan Karakter Berbasis Iman Dan Takwa. Yogyakarta: Teras.

Octavian, W. A. (2019) 'UPAYA PENINGKATAN PEMAHAMAN NILAIPANCASILA TERHADAP SISWA MELALUI KEGIATAN PENYULUHAN', 6(2), pp. 199-207.

Purwadarminta, W. (1984) Kamus Besar Bahasa Indonesia. Jakarta: Balai Pustaka.

Santoso (2017) 'Penanaman Nilai-Nilai Karakter Pada Siswa SD Pada Era Globalisasi', Prosiding Seminar Nasional: Aktualisasi Kurikulum 2013 di Sekolah Dasar melalui Gerakan Literasi Sekolah untuk Menyiapkan Generasi unggul dan Berbudi Pekerti, pp. 164-170.

Saprul, D. (no date) 'Implementasi Nilai-Nilai Pancasila di SMA Negeri 4 Palu', pp. 115.

Soejadi, K. R. (1994) Filsafat, Ideologi dan Wawasan Bangsa Indonesia. Jogjakarta: Universitas Atma Jaya. Sulistyarini (2015) 'Pengembangan karakter berbasis pancasila melalui pendidikan kewarganegaraan', Jurnal Bhinneka Tunggal Ika, 2(1), pp. 1-8.

Sutarjo Adisusilo (2012a) Pembelajaran Nilai - Karakter: Konstruktivisme dan VCT Sebagai Inovasi Pendekatan Pembelajaran Afektif. Jakarta: PT Raja Grafindo Persada.

Sutarjo Adisusilo (2012) Pembelajaran Nilai Karakter. Bandung: Rajawali Press.

Wafi, M. S. (2019) Pembelajaran Karakter Berbasis Pancasila, https://analisadaily.com/berita/arsip/2019/5/20/739597/pembelajarankarakterberbasis-pancasila/.

Wibowo, A. (2012) Pendidikan Karakter Usia Dini (Strategi Membangun Karakter di Usia Emas). Yogyakarta: Pustaka Pelajar.

Widiantari, D. (2017) 'CORE ETHICAL VALUES PENDIDIKAN KARAKTER (Berbasis Falsafah Negara)', MISYKAT: Jurnal IImu-ilmu Al-Quran, Hadist, Syari'ah dan Tarbiyah, 2(2), $\quad$ pp. 21-38. Available at: http://pps.iiq.ac.id/jurnal/index.php/MISYKAT/article/view/3.

Yusuf, H. (2013) Dasar-Dasar Aksiologis Pembukaan UUD 1945 Dalam Perspektif Filsafat Politik Islam. Bandar Lampung: An-Nur Pres. 